\title{
MODEL EKONOMI-EKOLOGI BERDASARKAN WTP PENGUNJUNG-WTA MASYARAKAT LOCAL DALAM PENGELOLAAN DESTINASI WISATA PANTAI PULISAN KABUPATEN MINAHASA UTARA
}

\author{
Paulus Adrian Pangemanan \\ Gene H. M. Kapantow \\ Melissa Tarore
}

\begin{abstract}
The purpose of this research This research develops a management model of tourist destinations that integrates economic and ecological development based on the suitability of pay (WTP) of visitors with the willingness to accept (WTA) of the local community, which is supported by the role of business actors and the government. This research focuses on identifying existing economic and ecological conditions, analyzing and formulating alternative activities for economic and ecological improvement based on the willingness to pay (WTP) -willingness to accept (WTA) indicator. This research was conducted for 10 months from March to December 2018, in the tourist destination area of Pulisan Beach, North Minahasa Regency. The results of the study concluded that the willingness to pay (WTP) analysis tool to accept (WTA) can produce a choice of tourism activities and products that are desired by tourists and accepted by the local community with the support of the government and business actors. The choice of activities and products can ensure sustainable use of resources, by strengthening conservation principles. This instrument can be adapted for the management of other resources that confront economic interests, and preserve the environment and resources.
\end{abstract}

Keywords: tourist destination, economic-ecology, willingness to pay (WTP)-willingness to accept (WTA), kuadroheliks

\begin{abstract}
ABSTRAK
Tujuan penelitian ini adalah mengembangkan model pengelolaan destinasi wisata yang mengintegrasikan pengembangan ekonomi dan ekologi berdasarkan persesuaian item (indikator) willingness to pay (WTP) pengunjung dengan willingness to accept (WTA) masyarakat local, yang didukung peran pelaku usaha dan pemerintah. Penelitian ini berfokus pada identifikasi kondisi eksisting unsur ekonomi dan ekologi, analisis dan perumusan alternative kegiatan untuk peningkatan ekonomi dan ekologi berdasarkan indikator willingness to pay (WTP)-willingness to accept (WTA). Penelitian ini dilaksanakan selama 10 bulan sejak Maret sampai Desember 2018, di wilayah destinasi wisata Pantai Pulisan Kabupaten Minahasa Utara. Hasil penelitian menyimpulkan bahwa instrumen analisis willingness to pay (WTP)-willingness to accept (WTA) dapat menghasilkan pilihan kegiatan dan produk wisata yang dihendaki wisatawan dan diterima masyarakat setempat dengan dukungan pemerintah dan pelaku usaha. Pilihan kegiatan dan produk dapat menjamin pemanfaatan sumberdaya secara berkelanjutan, dengan memperkuat prinsip konservasi. Instrumen ini dapat diadaptasi untuk pengelolaan sumberdaya lainnya yang memperhadapkan kepentingan ekonomi, dan kelestarian lingkungan dan sumberdaya.
\end{abstract}

Kata kunci: destinasi wisata, ekonomi-ekologi, wiilingness to pay (WTP)-willingness to accept (WTA), kuadroheliks

Agrisosioekonomi: 


\section{PENDAHULUAN}

\section{Latar Belakang}

Lokasi wisata pantai Pulisan terletak di Kecamatan Likupang Timur Kabupaten Minahasa Utara. Kecamatan Likupang Timur terkenal kaya dengan obyek wisata pesisir dengan pasir putih dan obyek wisata bawah laut (spot diving). Kawasan Wisata pantai Pulisan mudah di jangkau dari kota Manado dan wilayah lainnya di sekitar Manado. Waktu yang ditempuh untuk sampai di kawasan wisata ini diperkirakan 2 jam sampai dengan 3 jam dari pusat Kota Manado dengan menggunakan transportasi darat. Namun untuk menikmati keindahan alam pantai Pulisan harus menggunakan perahu sampai pada Tanjung Pulisan itu. Kekayaan dan keragaman obyek wisata laut di kawasan ini berpotensi untuk meningkatkan kunjungan, investasi maupun kegiatan ekonomi masyarakat. Hamparan pasir yang agak sedikit kecoklatan serta panorama laut lepas dan tenang menjadikan objek wisata ini menjadi salah satu tempat pilihan yang tepat untuk dijadikan tempat rekreasi. Pantai pulisan juga dikenal dengan taman lautnya yang indah serta bermacam - macam spesies ikan yang tinggal didalamnya, sangat cocok untuk para wisatawan yang mempunyai hobby diving dan snorkeling. Fasilitas - fasilitas yang terdapat di pantai pulisan ini masih sangat kurang, seperti kamar mandi/WC, gazebo, tempat sewa alat selam, rumah makan/kios. Jumlah kunjungan wisatawan di kawasan wisata Pulisan dipastikan melebihi data yang tercatat resmi di BPS Kabupaten (berdasarkan data tamu hotel atau wisatawan tercatat di agen perjalanan), karena banyak pengunjung yang tidak melapor tapi memasuki kawasan wisata di Minahasa Utara. Jarak ibu kota kecamatan Likupang Timur dari ibukota Kabupaten Minahasa Utara $\pm 39 \mathrm{Km}$, ditempuh dengan kendaraan 45 - 55 menit. Keragaman dan daya tarik wisata bahari di Pantai Pulisan dan sekitarnya belum dibarengi dengan ketersediaan sarana dan fasilitas yang memadai. Hasil survey yang dilakukan tim pengusul tahun 2017 menyimpulkan posisi pengelolaan kawasan wisata Pantai Pulisan dan sekitarnya dalam life cycle destinasi masih berada dalam fase involvement.
Kebijakan tol laut dan berbagai prioritas pembangunan kemaritiman, sangat potensial mendorong peningkatan signifikan kunjungan dan berbagai aktivitas ekonomi di kawasan ini. Berbarengan dengan peningkatan aktivitas wisatawan dan kegiatan ekonomi, degradasi sumberdaya dan kerusakan lingkungan akan meningkat. Peningkatan laju pembangunan/ pemanfaatan sumberdaya destinasi wisata bahari yang rawan (fragile resources), perlu diantisipasi dengan mengendalikan dan perlindungan sumberdaya. Konsep pembangunan berkelanjutan semakin mengemuka dalam pengelolaan destinasi wisata, dengan menekankan keseimbangan tiga aspek pembangunan yakni ekonomi, social, dan lingkungan (Koens et al, 2009; Barkin, 2003). Khusus dalam pengelolaan destinasi wisata, konsep ekowisata merupakan alat (tool) dari pembangunan berkelanjutan yang mempertemukan pertumbuhan ekonomi dengan pelestarian sumberdaya alam (Alexander, 2002;Libosada, 2009), sehingga menjadi solusi konflik kepentingan pelestarian sumberdaya alam, ekonomi dan social (Barkauskiene and Snieska, 2013).

Peran kuadroheliks berfokus pada item kegiatan ekonomi dan konservasi hasil analisis model ekonomi-ekologi yang dikembangkan tim peneliti. Model analisis ini mempertemukan kebutuhan dan kesediaan membayar (wiilingness to pay - WTP) pengunjung dengan kesediaan masyarakat memberikan layanan jasa dan produk (willingness to accept - WTA). Model analisis ini dapat menjadi instrument untuk menetapkan prioritas kegiatan ekonomiekologi yang menjamin pemanfaatan berkelanjutan dan perpanjangan life cycle destinasi.

\section{Perumusan Masalah}

Peningkatan jumlah wisatawan yang tidak terkontrol akan menyebabkan terdegradasinya sumberdaya alam di tempat wisata. Hal ini menjadi permasalahan apabila peran masyarakat, pelaku usaha wisata, pemerintah dan perguruan tinggi tidak memiliki pola dalam pengelolaan wisata pantai Pulisan secara berkelanjutan. 


\section{Manfaat Penelitian}

Terpolanya pengelolaan tempat wisata pantai Pulisan akan bermanfaat bagi masyarakat sekitar tempat wisata, para pengunjung serta pemerintah setempat agar destinasi wisata ini berkelanjutan.

\section{Tujuan Penelitian}

Tujuan penelitian ini adalah terpolanya peran kuadroheliks pariwisata (masyarakat, pelaku usaha wisata, pemerintah, perguruan tinggi) dalam pengelolaan berkelanjutan destinasi wisata Pantai Pulisan.

\section{METODE PENELITIAN}

\section{Lokasi dan Waktu Penelitian}

Penelitian ini dilaksanakan selama 10 bulan sejak Maret sampai Desember 2018, di wilayah destinasi wisata Pantai Pulisan Kabupaten Minahasa Utara.

\section{Model analisis dan instrumen WTP-WTA}

Tahun 2012 penulis memformulasi model analisis untuk optimalisasi manajemen destinasi berkelanjutan. Model analisis ini dipolarisasi pada:

(1) kesediaan wisatawan membayar produk dan jasa pariwisata dan kompensasi terhadap konservasi, diperhadapkan dengan.

(2) kesediaan masyarakat lokal menyediakan produk, jasa dan kegiatan pelestarian sumberdaya (alam, social- budaya) kepada wisatawan. Model analisis diperlihatkan pada Gambar 1.

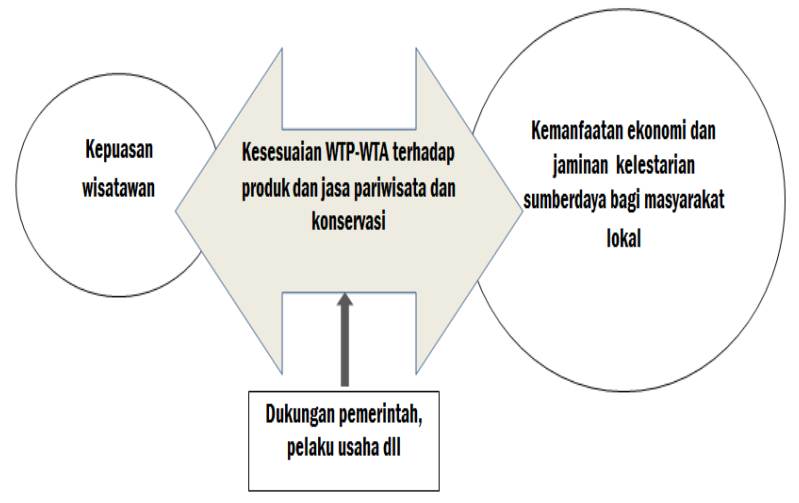

Gambar 1. Model analisis optimalisasi manajemen destinasi wisata berkelanjutan
Model analisis ini bersesuaian dengan asumsi yang dikemukakan oleh Scheyvens (1999), Wunder, (2000), Barkin (2003) bahwa kekuatan dan keberlanjutan ekowisata ditentukan terutama oleh interaksi wisatawan dengan masyarakat lokal. Selanjutnya, berdasarkan model analisis ini, dirancang instrumen untuk mengontrol: meningkatkan kesesuaian WTP-WTA dan mengarahkan produk dan kegiatan wisata pada peningkatan ekonomi dan/atau konservasi sumberdaya (alam dan social-budaya). Instrumen ini mencakup sejumlah indikator yang potensial dan realistik sesuai karakteristik destinasi. Diesendorf (2000), Stefanica and VlavianGurmeza (2010), dan Barkauskiene and Snieska (2013) mengemukakan bahwa komponen dimana dapat dilakukan pengukuran indikator pembangunan berkelanjutan meliputi: ekologi, ekonomi, dan sosial. Terkait dengan penekanan konservasi, Kiss (2004) mengemukakan bahwa strategi konservasi terbaik harus didasarkan pada pilihan penilaian yang realistis dan fisibel terkait keefektifan biaya, dampak sosial dan keberlanjutan. Indikator lingkungan dapat menunjukkan masalah yang sedang berlangsung dan menjadi acuan untuk merumuskan tindakan korektif untuk pencegahan, pengendalian dan konservasi sumberdaya. Nghi et al (2007) mengemukakan bahwa indicator-indikator pembangunan berkelanjutan dapat dinyatakan dalam nilai-nilai kuantitatif atau semi-kuantitatif untuk mengukur tingkat adaptasi lingkungan, sub system sosial-ekonomi dan kebutuhan wisatawan. Instrumen kesesuaian WTP WTA dibangun dari indikator-indikator pembangunan destinasi berkelanjutan yang diproyeksikan pada dimensi pertumbuhan ekonomi dan konservasi. Indikator yang dikembangkan berkaitan dengan permasalahan yang sedang berlangsung, dan produk atau kegiatan yang potensial dikembangkan untuk pertumbuhan ekonomi maupun konservasi sumberdaya (fisik, sosial-budaya). Tabel 1 adalah format pendataan WTP dan WTA atas indikator produk dan kegiatan yang memiliki dimensi ekonomi dan konservasi. 


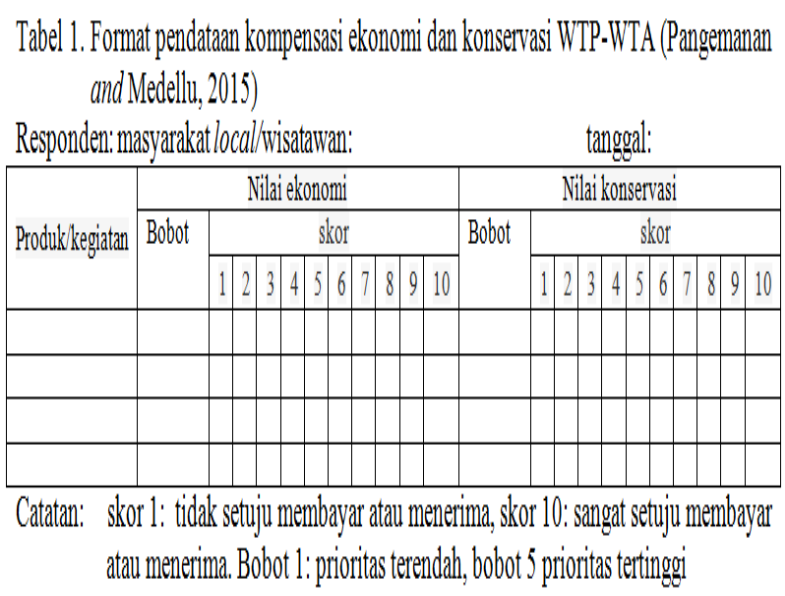

Pemetaan vektor WTP dan WTA dalam koordinat konservasi-pertumbuhan ekonomi

Rataan data WTP dan WTA (dari seluruh indicator dan seluruh responden) yang diperoleh dari format di atas (Tabel 1), dipetakan sebagai besaran vektor dalam sistem koordinat konservasi-pertumbuhan ekonomi. Gambar 2 memperlihakan vektor WTP dan WTA dalam sistem koordinat dengan absis skor konservasi sumberdaya (fisik dan sosial-budaya) dan ordinat skor pertumbuhan ekonomi.

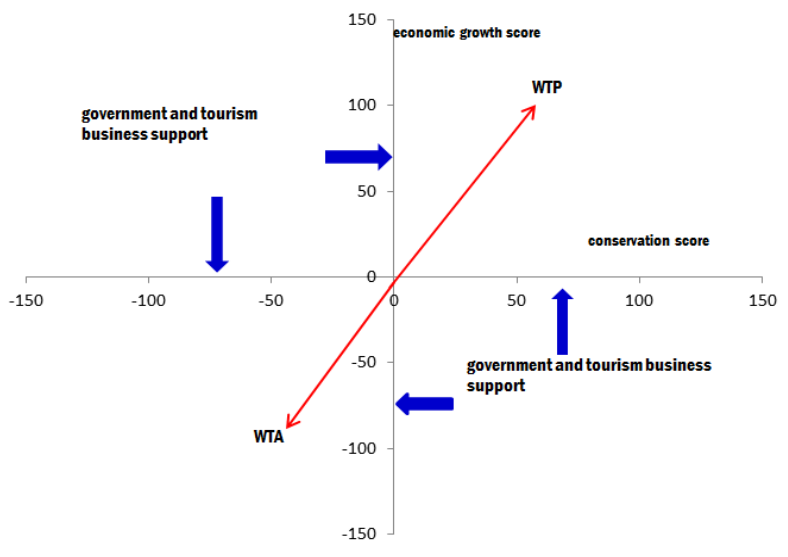

Gambar 2. Vektor WTP \& WTA dalam koordinat pertumbuhan ekonomi konservasi. Sumber: Pangemanan and Medellu, 2015

Titik pangkat vektor WTP dan WTA adalah posisi kondisi eksisting life cycle destinasi wisata. Ujung masing-masing vektor adalah skor (rataan) konservasi dan pertumbuhan ekonomi yang diperoleh menggunakan format pendataan WTP-WTA. Untuk mendeskripsikan kondisi eksisting, pendataan dapat dilakukan oleh peneliti atau oranglain berdasarkan fakta-fakta dari indikator konservasi dan pertumbuhan ekonomi.
Instrumen juga dapat digunakan untuk mengsimulasi dampak konservasi dan pertumbuhan ekonomi berdasarkan pilihan kegiatan (jasa dan produk) yang dihendaki wisatawan (WTP) dan diterima masyarakat lokal (WTA), dengan dukungan pemerintah dan pelaku usaha. Besarnya dukungan pemerintah dan pelaku usaha terhadap WTP dan WTA didasarkan pada skor dukungan menurut indikator instrumen WTP-WTA. Skor dukungan pemerintah dan WTA dikalikan dengan hasil perkalian bobot kegiatan dan skor pilihan wisatawan dan masyarakat, untuk menghasilkan skor komponen konservasi dan pertumbuhan ekonomi. Hasil simulasi ini penting untuk dijadikan acuan perencanaan dan pengendalian kegiatan yang menjamin keberlanjutan pemanfaatan sumberdaya.

Tingkat kesesuaian WTP wisatawan dengan WTA masyarakat menentukan keterlaksanaan pilihan kegiatan. Tingkat kesesuaian diperoleh dari perkalian titik (dot product) vektor WTP dengan WTA. Nilai maksimum WTP.WTA adalah -1, menunjukkan potensi maksimum keterlaksanaan kegiatan yang dihendaki wisatawan dan diterima masyarakat. Tanda negatif menunjukkan kedua vektor berlawanan arah. Vektor WTP terletak di kuandran pertama dan vektor WTA di kuadran ketiga. Kolinieritas kedua vektor yang menunjuk potensi keterlaksanaan kegiatan dapat dikendalikan oleh peran pemerintah dan pelaku usaha. Tendensi kegiatan untuk penguatan komponen konservasi atau pertumbuhan ekonomi bergantung pada arah vektor WTP dan WTA. Jika vektor WTP dan WTA lebih dekat dengan sumbu konservasi, maka kegiatan akan lebioh memperkuat komponen konservasi, demikian sebaliknya. Arah vektor yang juga dapat dikendalikan oleh peran pemerintah dan pelaku usaha.

\section{Hasil Analisis Kuadrohelix Pantai Pulisan}

Hasil identifikasi kegiatan yang telah dilaksanakan dan yang potensial dikembangkan di kawasan wisata Pantai Pulisan berkaitan dengan konservasi dan peningkatan ekonomi meliputi 22 kegiatan (a.l. pencangkokan karang, pembersihan sampah plastic dll). Hasil penilaian 22 kegiatan yang telah ada 
mendeskripsikan kondisi eksisting vektor WTP dan WTA seperti pada Gambar 3 (anak panah berwarna merah). Hasil simulasi 22 kegiatan (termasuk 22 kegiatan yang telah ada) yang datanya diperoleh dari wisatawan, penduduk local, pemerintah dan pelaku usaha menghasilkan dua scenario. Skenario-1 ditunjukkan oleh anak panah berwarna hijau dan skenario-2 ditunjukkan oleh anak panah berwarna biru. Perbedaan skenario-1 dan skenario-2 terletak pada faktor dukungan pemerintah dan pelaku usaha. Dukungan pemerintah dan pelaku usaha terhadap pilihan kegiatan WTP-WTA yang memberikan peningkatan/penguatan komponen konservasi, lebih besar pada skenario-1 dibanding skenario-2. Hasil pengujian kolinieritas vektor WTP - WTA untuk kondisi eksisting, skenario1 , dan skenario-2 masing-masing adalah - 0.88 , - 0.95, dan - 0.96. Tingkat kolinieritas WTPWTA pada kondisi eksisting sebesar - 0.98 menunjukkan bahwa interaksi wisatawan dengan masyarakat lokal dalam konservasi sumberdaya dan pertumbuhan ekonomi (pendapatan masyarakat lokal) sudah cukup baik, namun perlu ditingkatkan baik melalui produk dan kegiatan alternatif, serta dukungan pemerintah dan pelaku usaha.

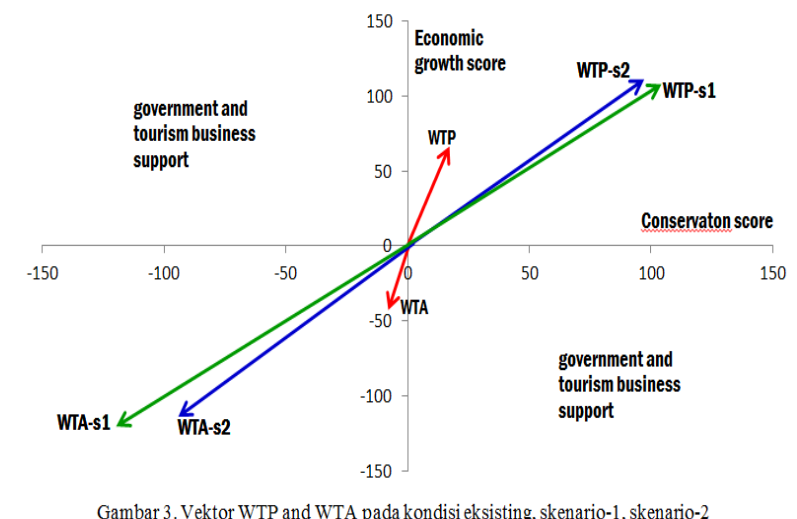

Pilihan kegiatan yang dihendaki wisatawan dan diterima masyarakat dengan dukungan pemerintah dan pelaku usaha menghasilkan tingkat persesuaian WTP dan WTA seperti pada skenario-1 dan skenario-2, yang lebih tinggi dari kondisi eksisting. Hasil ini menunjukkan bahwa penggunaan instrumen ini dapat meningkatkan produktivitas wisata serta jaminan konservasi sumberdaya alam, sosial-budaya). Hasil pemetaan vector menunjukkan bahwa skenario-1 merupakan pilihan yang paling besar mengkontribusi konservasi sumberdaya.

\section{Kesimpulan}

Instrumen analisis WTP-WTA dapat menghasilkan pilihan kegiatan dan produk wisata yang dihendaki wisatawan dan diterima masyarakat setempat dengan dukungan pemerintah dan pelaku usaha. Pilihan kegiatan dan produk dapat menjamin pemanfaatan sumberdaya secara berkelanjutan, dengan memperkuat prinsip konservasi. Instrumen ini dapat diadaptasi untuk pengelolaan sumberdaya lainnya yang memperhadapkan kepentingan ekonomi, dan kelestarian lingkungan dan sumberdaya.

\section{Saran}

Model kuadrohelix yang diperoleh dari penelitian ini dapat digunakan untuk keberlanjutan pengelolaan sumberdaya alam di destinasti wisata Pantai Pulisan sebagai rekomendasi agar masyarakat, Pemerintah dan para pengunjung mengetahui bagaimana pelestarian sumberdaya disekitar tempat wisata.

\section{DAFTAR PUSTAKA}

Alexander C. O'Neill. 2002. What Globalization Means for Ecotourism: Managing Globalization's Impacts on Ecotourism in Developing Countries. Indiana Journal of Global Legal Studies: 9(2): $501-528$.

Barkauskiene K and V. Snieska. 2013, Ecotourism as an untegral part of sustainable tourism development. Economics and Management, 18(3): 449 $-456$.

Barkin D. 2003. Alleviating poverty through ecotourism: Promises and reality in the Monarch butterfly reserve of Mexico. Environment, Development and Sustainability, 5: 371-382. 
Diesendorf, M., 2000, 'Sustainability and sustainable development', in Dunphy, D, Benveniste, J, Griffiths, A and Sutton, P (eds) Sustainability: The corporate challenge of the 21st century, Sydney: Allen \&Unwin, chap. 2, 1937.

Kiss A. 2004. Is community-based ecotourism a good use of biodiversity conservation funds?. TRENDS in Ecology and Evolution, 19 (5): $232-237$.

Koens J.F., C. Dieperink, and M. Miranda. 2009. Ecotourism as a development strategy: experiences from Costa Rica. Environ Dev Sustain, 11:1225-1237.

Libosada C.M. 2009. Business or leisure? Economic development and resource protection - Concepts and practices in sustainable ecotourism. Ocean \& Coastal Management 52: 390-394.

Medellu Ch., and Pangemanan P., 2015. WTPWTA instrument for controlling the tourism destination life-cycle. Paper presented at IcoMensed seminar, August $7-9,2015$.
Scheyvens R (1999) Ecotourism and the empowerment of local communities. Tourism Manage 20: 245-249.

Stefanica, M. and M. Vlavian-Gurmeza. 2010. Ecotourism - model of sustainable tourist development. Studies and Scientific Researches, 15, 480-486

Nghi T., N. T. Lan, N. D. Thai, D. Mai, and D. X. Thanh. 2007. Tourism carrying capacity assessment for PhongNha - Ke Bang and Dong Hoi, QuangBinh Province. VNU Journal of Science, Earth Sciences 23: 80-87

Wunder, S. 2000. Ecotourism and economic incentives: an empirical approach. Ecol. Econ. 32, 465-479. 